\title{
Association between Brand Architecture and Brand Concept-An Exploration Based on Primary Survey
}

\author{
R Harish
}

\section{Abstract}

This paper explores the linkage between brand concepts (functional, experiential, symbolic and relational) and brand architecture typologies (product, dual and corporate) considering popular and successful consumer brands marketed in India. This study in fact draws upon an earlier conceptual paper, which recommended a framework of strong relationships between brand concepts and brand architectures based on anecdotal evidence of prominent examples. But this framework had not been empirically tested out through analysis using a large sample from actual industry practice. Observation of data gathered in the present study (including through consumer survey) indicates that the relationships between brand architectures and brand concepts are in partial alignment with the framework proposed in the earlier study. The deviations are mainly due to various other factors which also influence the brand architectures of companies. Further research could also suggest some modifications to the BASE model itself, to suit specific contexts.

Keywords: Brand concept, Brand architecture, Brand architecture Strategy explorer, Brand structure, Brand hierarchy

Dean (Academics), IBS Business School, Bangalore, India; harishr58@gmail.com 


\section{Introduction}

The motivation for this research stems from a paper by Strebinger (2004), which proposed an explorative model for deriving brand architecture strategies - called BASE (i.e., Brand Architecture Strategy Explorer). This conceptual model was arrived at by integrating three fields of theory - (a) strategic brand concepts, (b) theory of information processing, and (c) brand architecture typologies. The possible link between strategic brand concepts and brand architecture typologies comes out strongly in this paper, and forms the focus of the present research. While Strebinger argued out the rationale for his model based on logical reasoning and anecdotal evidence, no empirical research appears to have been conducted so far to test this model. This paper aims to fill this gap through a consumer survey conducted in the Indian context. This paper investigates the extent to which BASE is implemented in actual practice by marketers in India, thus examining the practical application and relevance of the instrument proposed by Strebinger.

\subsection{Background - Brand Architecture Strategy Explorer}

A summary of Strebinger's (2004) paper is presented here to provide the requisite background and thus facilitate further understanding. The emphasis here is on explaining the proposed association between brand architecture types and strategic brand concepts.

Strebinger, considers five standard brand architecture strategies by integrating the varied brand architecture typologies proposed by renowned advocates on this subject such as Aaker \& Joachimsthaler (2000), Kapferer(1997) and others. A brief explanation of these brand architecture typologies is given below.

1. Corporate brand strategy (C-branding), which adopts a uniform brand (i.e., the corporate name or an umbrella brand name) for all product categories and target groups.

2. Product brand strategy (P-branding), wherein each product category of the company has an independent brand name. 
3. Target group brand strategy (T-branding), where the company offers multiple products to each target group, with a common brand name for all products marketed to a given target group.

4. Product and target-group specific brand strategy (PTbranding), where each combination of product category and target group is given a distinct brand name.

5. Brand family strategy (F-branding), where the company adopts a hierarchical or dual branding structure, with a common endorser (often a company brand name) and several endorsed brands or sub-brands (i.e., brand names of individual products or product groups) with their own personalities.

Figure 1 offers a diagrammatic representation of the five brand architecture strategies or typologies used by Strebinger.

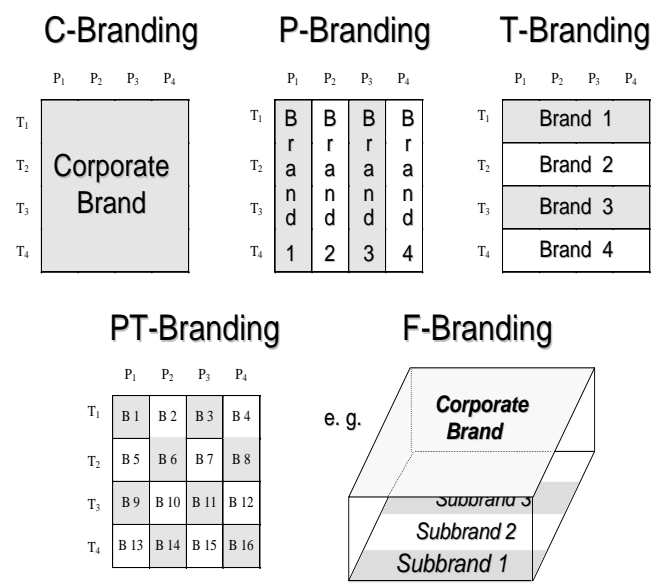

Fig 1: Brand Architecture Strategies

(Source: Strebinger, 2004)

Strebinger also considers four strategic brand concepts. Three of these - functional, experiential and symbolic - are those identified by Park et al (1986) as part of their Brand Concept Management (BCM) framework for selecting, implementing and controlling brand image to enhance market performance. To these, Strebinger 
added a fourth one - relational. The four brand concepts are explained in brief below.

1. Functional brand concept -Promises intrinsic advantages of product consumption through technical superiority, higher durability, reliability or just good value for money. This concept has an integrative effect on brand architecture (i.e., a common brand name is likely to be used for a wide range of products).

2. Experiential brand concept - Relates to sensual experience of the product through the five senses. This is about what it feels like to use the product, which can correspond to both product-related and non-product related attributes and includes sensory pleasure, variety and cognitive stimulation. This has a separative effect on brand architecture by product categories (i.e., different brand names would tend to be used for different products or product categories).

3. Symbolic brand concept - Emphasizes non-product related extrinsic advantages of the product, which enable the buyer to express personality, values and status, and thus enhance out-directed self-esteem (prestige) and social selfpresentation. This has a separative effect on brand architecture by target groups.

4. Relational brand concept - Evokes emotional attachment with the brand and imparts a sense of familiarity with the brand, based on sympathy, attachment and trust. This concept has an integrative impact on brand architecture.

It is important to note that the strategic brand concepts are not linked to specific product categories. Functional, experiential, symbolic or relational concepts can be applied to most products. Further, most brands do not correspond to one "pure" form, but are a mixture of two or more of these concepts. However, one of the concepts could be more dominant than the others. 
The linkages proposed by BASE between brand concepts and brand architecture strategies are shown in Figure 2, and the explanation thereof is provided in the paragraphs below.

BASE proposes that companies with a product portfolio having primarily functional and relational positioning or a combination of the two would benefit from a C-branding strategy, as these concepts can conveniently embrace an extensive variety of products offered or target groups served.

If a company's product range encompasses symbolic concepts, BASE recommends a T-branding strategy. For example, luxury brands successfully unite a broad variety of products under one brand, as the image of the typical brand users and the benefits desired by the target group are uniform.

BASE recommends a P-branding strategy when a company has a number of products with different experiential characteristics.

If a company's product range comprises combinations of symbolic and experiential brand concepts, it should resort to PT-branding, which is the most separative and costliest form of brand architecture. Here, in each product category, there would be different brands to address different target segments.

Combinations of experiential and relational brand concepts, symbolic and functional concepts, and mixtures which contain three or all four of the brand concepts, would benefit by Fbranding. Where there are large markets with a high degree of product and target group heterogeneity, it would be worthwhile complementing the corporate brand with specific sub-brands at product or target group level, thus leading to F-branding. If the functional or relational concept is more dominant, the C-brand would be in the driver's seat. On the other hand, if the experiential or symbolic concept is more important, the $\mathrm{P}$ or $\mathrm{T}$ brand would be at the front end, with the C-brand playing the role of a tacit endorser. 


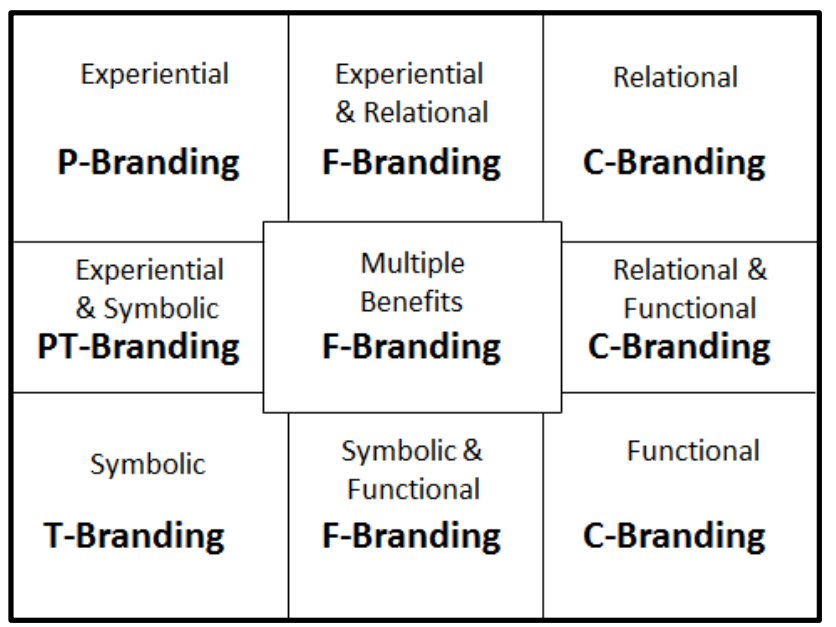

Fig 2: BASE - Linking Strategic Brand Concept to Brand Architecture Strategy

(Source: Adapted from Strebinger, 2004)

Thus, by linking five brand architecture strategies with four strategic brand concepts, the Brand Architecture Strategy Explorer (BASE) proposes standard brand architecture strategies for various strategic brand concepts. This is proposed as an explorative model that can assist in making strategic brand architecture decisions within the framework of its limitations. An important limitation is that many companies have a mixture of functional, experiential, symbolic and relational offerings, and a brand architecture that has developed over time (often through mergers and acquisitions), may not follow the pattern suggested by BASE.

\section{Research Objective}

The BASE framework has been proposed based on anecdotal evidence and logical reasoning. Prima facie, it appears plausible and meaningful. It would be appropriate to use corporatedominant branding when the predominant brand concept is functional (e.g., Wal-Mart - known for its strong value for money advantage) or relational (e.g., Tata is held in high esteem as a trustworthy brand). Product brands are more relevant when the brand concept is oriented towards experiential and/or symbolic, so 
that the concepts can be positioned sharply and communicated effectively to consumers. Family branding or dual branding would be suitable when two brand concepts are to be conveyed simultaneously, with the parent brand (corporate brand) and the sub-brand (product brand) bringing together two different concepts. One can find numerous instances which seem to fit this model.

At the same time, there are many examples which do not conform to this model. A sizeable percentage of product brands are positioned based on the functional concept. There are also many instances where competing brands in the same product category have different brand concepts, but follow the same brand architecture. Therefore, there is a clear need for exploring the BASE framework through a study of numerous examples from diverse product categories, and that too in the Indian context. This forms the core objective of this research.

In other words, the research objective is to explore whether and to what extent there is association between brand concepts and brand architecture types among consumer product and service brands marketed in India (by both Indian and multinational companies). And if there is such an association, the objective is also to identify the nature and extent of such association.

\section{Methodology}

\subsection{Source of Brands Included in the Research}

The Nielsen Most Trusted Brands Survey of 2013 (Nielsen, 2013) is the primary source of brands and companies included in this research. Nielsen's Most Trusted Brands Survey of 2008 (Nielsen, 2008) has also been used where required to bring in adequate diversity in the brands used for the study and to fill in missing or under-represented product/service categories.

Nielsen has been conducting an annual survey of India's Most Trusted Brands since 2001, which is published in the Brand Equity Supplement of the Economic Times, a daily business newspaper published in India. This survey ranks the brands based on respondents' rating on quality, value for money, recommendation and understanding of consumer need. Among the top 100 most 
trusted brands of 2008, 74 continued to be on the list in 2013. The Nielsen survey encompasses brands across all consumer product and service categories. The sampling frame covers representative metro, tier I and tier II cities in all four regions of the country, and includes respondents of varied income and age categories. The brands that emerge as the leading ones in this survey are those that reach out to a wide cross section of people, and are truly representative of consumer product and service brands that are marketed extensively across the length and breadth of India. Most middle class Indian consumers would be familiar with a majority of these brands, thus making it easy to obtain reliable and valid consumer responses about these brands.

\subsection{Methodology for Deciding the Brands' Concept and Architecture}

There are two things that we need to identify for each of the brands to be studied as part of this research - its brand concept and brand architecture. Once these are known, the platform would be set for analysing the association between the two, if any.

The brand concept is decided by the marketer, the brand manager or the advertising agency, though they may not use the terminologies or framework proposed by Park et al (1986). The brand concept is thereafter conveyed to consumers through the marketing mix, especially by way of marketing communications, and in particular through advertising.

It would be extremely difficult to get the marketing professionals or advertising agencies of numerous companies and brands to respond to queries and articulate the brand concepts in the manner required for the study. Therefore, a second alternative is for the researcher to decide the brand concept based on the company's marketing communications. Yet another option is to arrive at the same through a consumer survey. The brand concept ultimately is what the consumers perceive it to be. Therefore, this third approach has been followed in this research for arriving at the concepts applicable to the brands under study.

The brand architecture applicable to each brand is decided by the researcher, as this is readily evident from the branding structure followed by each company. There is no need to approach the 
companies, and this is not easy to derive from consumer responses, as most consumers are not overtly conscious of the brand architectures followed by marketers, nor are they aware of this concept.

\subsection{Brand Architecture Types Considered in the Study}

Though Strebinger uses five brand architecture typologies including T-Branding and PT-Branding, these two are in fact subvarieties of either C-Branding or P-Branding.

A target brand (T-Brand) is a brand under which multiple products are offered to the same target group. For example, luxury brands like Louis Vuitton offer a wide variety of products under a single brand name, targeted at a specific market segment. A T-Brand is more often a corporate brand, but could also be a product brand, depending on the situation.

A product-target brand (P-T Brand) is a product brand that is aimed at a specific target segment. In P-T Branding, the same company offers multiple product brands in each product category to address different target segments. For instance, Hindustan Unilever offers three PT brands - Surf Excel, Rin and Wheel - all in the same product category (fabric care detergents), but aimed at different target market segments. This is however not a brand architecture strategy followed across the entire company.

Therefore, it is not necessary to make such fine distinctions; all the more so, as the number of examples which can be clearly classified as T-Branding and PT-Branding are not many.

Thus, for the purpose of this study, we would have only three types of brand architecture - C-Branding (i.e., corporate dominant brand architecture), F-Branding (which we refer to as Dual Branding, identified by the letter $\mathrm{D}$ to avoid possible confusion with the Functional brand concept, which we identify by the letter F) and P-Branding (i.e., product branding).

A given brand is classified as $\mathrm{C}$, if it is a corporate or umbrella brand name, though the company may be using different branding structures and nomenclatures for different products. The logic is that our primary objective is to explore what brand concept(s) corporate brands are linked to. 
A given brand is classified as $\mathrm{D}$, if it is a sub-brand in a dual brand structure (e.g., KitKat, which is the sub-brand in the dual brand Nestle KitKat) or where the complete dual name is commonly used (e.g., TVS Scooty). A brand nomenclature is considered as a dual brand if two brand names (i.e., a parent brand name and a subbrand name) are both used on the packaging, product or in the advertising. Use of the parent brand name or company name only as part of the address or use of the company logo in very small size on the package (e.g., ITC and Unilever logos appearing on product packages) or at the end of an audio-visual advertisement (examples: Logos of Unilever, P\&G and Nestle are often shown at the end of audio-visual advertisements) is not considered as dual branding.

Names like Maruti-Suzuki, Colgate-Palmolive or SmithKline Beecham are also not considered as dual brand names. These are corporate names which have emerged with a dual name structure as a result of joint ventures, mergers or acquisitions.

A given brand is classified as $\mathrm{P}$, if it applies to a specific product or product category, and is used independently, without reference to the name of the company.

\subsection{Brand Concepts Used in the Study}

The brand concepts used in this study are - Functional (F), Experiential (E), Symbolic (S) and Relational (R), which have already been explained earlier in this paper.

\subsection{Classification of Brands by Brand Concepts}

Respondents were provided with a brief written description of the four brand concepts and were asked to classify brands as being Functional, Experiential, Symbolic or Relational, based on their exposure to and experience with the brands. The concept which received the highest percentage of consumer responses was identified as the predominant brand concept applicable to the brand. In case a second or third brand concept received at least $50 \%$ of the responses received against the predominant brand concept, these too were considered, thus classifying the brand as exhibiting mixed or multiple concepts. 


\subsection{Profile of Respondents}

The respondents were middle class and upper middle class urban Indian youth, most of them in their 20s, with male and female respondents being roughly in the ratio of 60:40. The respondents hailed from different parts of India, and were residents of Bangalore in southern India. Most of the respondents were graduates. About half of them were students. Around half of them had no work experience and majority of the rest had work experience of less than four years. Some of them had family businesses. A convenience sampling method was used with the objective of getting responses from educated, urban, middle class youth. This group was considered as representative of the modern urban Indian middle class, which formed the prime target market segment for the products and services being studied.

\section{Results of the Survey}

We now look at the data and the outcome of the survey, and analyse the same with reference to the BASE model.

The survey had 92 respondents. The respondents were given a list of 100 well-known brands across various categories, and were required to specify one brand concept against each brand, Functional (F), Experiential (E), Symbolic (S) or Relational (R), depending on their perception of the brand. The meanings of each of these concepts were explained in the opening note to the questionnaire. The respondents labelled only those brands that they were familiar with, as F, E, S or R. Thus, different brands received different number of responses.

The number of responses received against each brand; percentage scores for the concepts F, E, S and R; the brand concept(s) identified for each brand based on the percentage scores (refer the section "Classification of Brands by Brand Concepts" earlier above.) and also the brand architecture type as identified by the researcher, are all presented in Table 1 . 
Table 1: Brand Concept Score Percentage, Brand Concepts, and Brand Architecture

\begin{tabular}{|c|c|c|c|c|c|c|c|c|}
\hline \multirow{2}{*}{$\begin{array}{l}\dot{z} \\
\dot{z} \\
\dot{m}\end{array}$} & \multirow{2}{*}{ 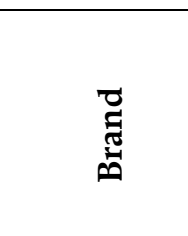 } & \multirow{2}{*}{ 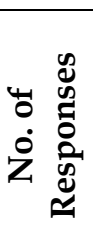 } & \multicolumn{4}{|c|}{$\begin{array}{c}\text { Brand Concept Score } \\
\%\end{array}$} & \multirow{2}{*}{ 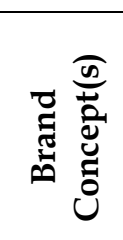 } & \multirow{2}{*}{ 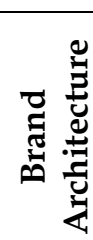 } \\
\hline & & & $\mathbf{F}$ & E & S & $\mathbf{R}$ & & \\
\hline A & \multicolumn{8}{|c|}{ Soaps \& Personal Wash } \\
\hline 1 & Cinthol & 73 & 44 & 36 & 11 & 10 & $\mathrm{~F}, \mathrm{E}$ & $\mathrm{D}$ \\
\hline 2 & Dove & 85 & 16 & 47 & 26 & 11 & E,S & $\mathrm{P}$ \\
\hline 3 & Hamam & 64 & 63 & 16 & 8 & 14 & $\mathrm{~F}$ & $\mathrm{P}$ \\
\hline 4 & Lifebuoy & 80 & 66 & 16 & 5 & 13 & $\mathrm{~F}$ & $\mathrm{P}$ \\
\hline 5 & Lux & 86 & 36 & 35 & 16 & 13 & $\mathrm{~F}, \mathrm{E}$ & $\mathrm{P}$ \\
\hline 6 & Medimix & 70 & 70 & 11 & 4 & 14 & $\mathrm{~F}$ & $\mathrm{P}$ \\
\hline 7 & Pears & 83 & 24 & 48 & 18 & 10 & $\mathrm{E}, \mathrm{F}$ & $\mathrm{P}$ \\
\hline 8 & Santoor & 62 & 45 & 31 & 13 & 11 & $\mathrm{~F}, \mathrm{E}$ & $\mathrm{P}$ \\
\hline 9 & Vivel & 57 & 39 & 26 & 26 & 9 & $\mathrm{~F}, \mathrm{E}, \mathrm{S}$ & $\mathrm{P}$ \\
\hline B & \multicolumn{8}{|c|}{ Other Personal Care } \\
\hline 10 & $\begin{array}{l}\text { Clinic } \\
\text { Plus }\end{array}$ & 56 & 46 & 34 & 13 & 7 & $\mathrm{~F}, \mathrm{E}$ & $\mathrm{P}$ \\
\hline 11 & Dettol & 88 & 65 & 14 & 6 & 16 & $\mathrm{~F}$ & $\mathrm{P}$ \\
\hline 12 & $\begin{array}{l}\text { Fair \& } \\
\text { Lovely }\end{array}$ & 67 & 28 & 37 & 19 & 15 & $\mathrm{E}, \mathrm{F}, \mathrm{S}$ & $\mathrm{P}$ \\
\hline 13 & Garnier & 61 & 16 & 25 & 39 & 20 & S,E,R & $\mathrm{C}$ \\
\hline 14 & $\begin{array}{l}\text { Head \& } \\
\text { Shoulders }\end{array}$ & 72 & 40 & 33 & 15 & 11 & $\mathrm{~F}, \mathrm{E}$ & $\mathrm{P}$ \\
\hline 15 & $\begin{array}{l}\text { Johnson \& } \\
\text { Johnson }\end{array}$ & 75 & 16 & 29 & 20 & 35 & $\mathrm{R}, \mathrm{E}, \mathrm{S}$ & $\mathrm{C}$ \\
\hline 16 & Lakme & 64 & 19 & 28 & 30 & 23 & $\mathrm{~S}, \mathrm{E}, \mathrm{R}, \mathrm{F}$ & $\mathrm{C}$ \\
\hline 17 & Pantene & 56 & 29 & 39 & 21 & 11 & $\mathrm{E}, \mathrm{F}, \mathrm{S}$ & $\mathrm{P}$ \\
\hline 18 & Pond's & 74 & 30 & 38 & 12 & 20 & $\mathrm{E}, \mathrm{F}, \mathrm{R}$ & $C$ \\
\hline 19 & Sunsilk & 62 & 34 & 44 & 8 & 15 & $\mathrm{E}, \mathrm{F}$ & $\mathrm{P}$ \\
\hline 20 & Vaseline & 66 & 47 & 21 & 11 & 21 & $\mathrm{~F}$ & $\mathrm{P}$ \\
\hline
\end{tabular}


R Harish Association between Brand Architecture and Brand Concept

\begin{tabular}{|c|c|c|c|c|c|c|c|c|}
\hline \multirow{2}{*}{$\begin{array}{l}\dot{z} \\
\dot{m}\end{array}$} & \multirow{2}{*}{ 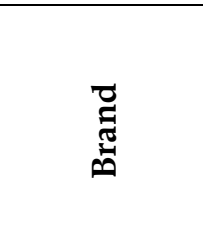 } & \multirow{2}{*}{ 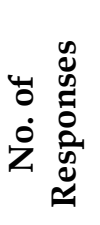 } & \multicolumn{4}{|c|}{$\begin{array}{c}\text { Brand Concept Score } \\
\%\end{array}$} & \multirow{2}{*}{ 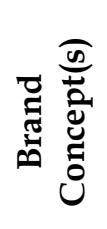 } & \multirow{2}{*}{ 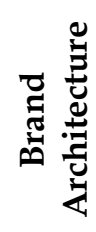 } \\
\hline & & & $\mathbf{F}$ & E & S & $\mathbf{R}$ & & \\
\hline C & \multicolumn{8}{|c|}{ OTC Healthcare } \\
\hline 21 & Amrutanjan & 49 & 55 & 20 & 10 & 14 & $\mathrm{~F}$ & $\mathrm{C}$ \\
\hline 22 & Band-Aid & 63 & 51 & 11 & 13 & 25 & $\mathrm{~F}$ & $\mathrm{P}$ \\
\hline 23 & Boroplus & 51 & 47 & 29 & 6 & 18 & $\mathrm{~F}, \mathrm{E}$ & $\mathrm{D}$ \\
\hline 24 & Crocin & 68 & 57 & 18 & 7 & 18 & $\mathrm{~F}$ & $\mathrm{P}$ \\
\hline 25 & D-Cold & 52 & 63 & 21 & 4 & 12 & $\mathrm{~F}$ & $\mathrm{P}$ \\
\hline 26 & Iodex & 59 & 54 & 14 & 2 & 31 & $\mathrm{~F}, \mathrm{R}$ & $\mathrm{P}$ \\
\hline 27 & Moov & 69 & 36 & 25 & 12 & 28 & $\mathrm{~F}, \mathrm{R}, \mathrm{E}$ & $\mathrm{P}$ \\
\hline 28 & Saridon & 52 & 62 & 15 & 6 & 17 & $\mathrm{~F}$ & $\mathrm{P}$ \\
\hline 29 & Vicks & 77 & 44 & 22 & 6 & 27 & $\mathrm{~F}, \mathrm{R}, \mathrm{E}$ & $\mathrm{P}$ \\
\hline 30 & $\begin{array}{l}\text { Zandu } \\
\text { Balm }\end{array}$ & 66 & 59 & 20 & 3 & 18 & F & C \\
\hline D & \multicolumn{8}{|c|}{ Fabric Care } \\
\hline 31 & Ariel & 69 & 39 & 25 & 23 & 13 & $\mathrm{~F}, \mathrm{E}$ & $\mathrm{P}$ \\
\hline 32 & Fena & 41 & 78 & 7 & 2 & 12 & $\mathrm{~F}$ & $\mathrm{C}$ \\
\hline 33 & Ghari & 40 & 83 & 13 & 0 & 5 & $\mathrm{~F}$ & $\mathrm{C}$ \\
\hline 34 & Nirma & 54 & 57 & 17 & 6 & 20 & $\mathrm{~F}$ & $\mathrm{C}$ \\
\hline 35 & Rin & 79 & 51 & 23 & 8 & 19 & $\mathrm{~F}$ & $\mathrm{P}$ \\
\hline 36 & Robin Blue & 56 & 63 & 21 & 9 & 7 & $\mathrm{~F}$ & $\mathrm{P}$ \\
\hline 37 & Surf & 79 & 37 & 22 & 15 & 27 & $\mathrm{~F}, \mathrm{R}$ & $\mathrm{P}$ \\
\hline 38 & Tide & 71 & 51 & 27 & 10 & 13 & $\mathrm{~F}, \mathrm{E}$ & $\mathrm{P}$ \\
\hline 39 & Ujala & 62 & 58 & 15 & 13 & 15 & $\mathrm{~F}$ & $\mathrm{P}$ \\
\hline 40 & Wheel & 57 & 67 & 7 & 7 & 19 & $\mathrm{~F}$ & $\mathrm{P}$ \\
\hline $\mathbf{E}$ & \multicolumn{8}{|c|}{ Household Care } \\
\hline 41 & All-Out & 71 & 52 & 17 & 10 & 21 & $\mathrm{~F}$ & $\mathrm{P}$ \\
\hline 42 & Domex & 53 & 62 & 23 & 11 & 4 & $\mathrm{~F}$ & $\mathrm{P}$ \\
\hline 43 & Fevicol & 83 & 55 & 10 & 10 & 25 & $\mathrm{~F}$ & $\mathrm{P}$ \\
\hline 44 & $\begin{array}{l}\text { Good } \\
\text { Knight }\end{array}$ & 78 & 46 & 23 & 5 & 26 & $F, R, E$ & $\mathrm{P}$ \\
\hline 45 & Harpic & 65 & 55 & 15 & 15 & 14 & $\mathrm{~F}$ & $\mathrm{P}$ \\
\hline
\end{tabular}




\begin{tabular}{|c|c|c|c|c|c|c|c|c|}
\hline \multirow{2}{*}{$\begin{array}{l}\dot{z} \\
\dot{m}\end{array}$} & \multirow{2}{*}{ 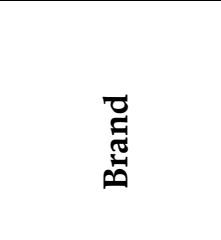 } & \multirow{2}{*}{ 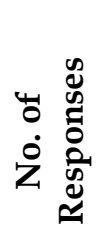 } & \multicolumn{4}{|c|}{$\begin{array}{c}\text { Brand Concept } \\
\text { Score } \%\end{array}$} & \multirow{2}{*}{ 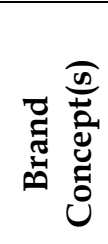 } & \multirow{2}{*}{ 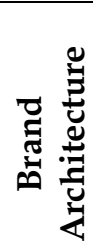 } \\
\hline & & & $\mathbf{F}$ & E & S & $\mathbf{R}$ & & \\
\hline E & \multicolumn{8}{|c|}{ Household Care } \\
\hline 46 & Henko & 50 & 70 & 16 & 6 & 8 & $\mathrm{~F}$ & $\mathrm{P}$ \\
\hline 47 & Lizol & 39 & 67 & 23 & 3 & 8 & $\mathrm{~F}$ & $\mathrm{P}$ \\
\hline 48 & Mortein & 60 & 72 & 15 & 7 & 7 & F & $\mathrm{P}$ \\
\hline 49 & Pril & 45 & 73 & 9 & 7 & 11 & $\mathrm{~F}$ & $\mathrm{P}$ \\
\hline 50 & Vim & 65 & 54 & 22 & 11 & 14 & $\mathrm{~F}$ & $\mathrm{P}$ \\
\hline F & \multicolumn{8}{|c|}{ Chocolates \& Confectionery } \\
\hline 51 & 5 Star & 77 & 13 & 43 & 13 & 31 & E,R & $\mathrm{D}$ \\
\hline 52 & Big Babol & 51 & 33 & 41 & 20 & 6 & $\mathrm{E}, \mathrm{F}$ & $\mathrm{P}$ \\
\hline 53 & Center Fresh & 61 & 31 & 43 & 10 & 16 & $\mathrm{E}, \mathrm{F}$ & $\mathrm{P}$ \\
\hline 54 & Dairy Milk & 89 & 9 & 35 & 8 & 48 & $\mathrm{R}, \mathrm{E}$ & $\mathrm{D}$ \\
\hline 55 & Gems & 58 & 21 & 47 & 10 & 22 & $E$ & $\mathrm{D}$ \\
\hline 56 & Hajmola & 70 & 31 & 37 & 11 & 20 & $\mathrm{E}, \mathrm{F}, \mathrm{R}$ & $P$ \\
\hline 57 & Kit Kat & 73 & 14 & 59 & 7 & 21 & $E$ & $\mathrm{D}$ \\
\hline 58 & Mint-o-Fresh & 56 & 34 & 52 & 7 & 7 & $\mathrm{E}, \mathrm{F}$ & $\mathrm{P}$ \\
\hline 59 & Munch & 62 & 21 & 52 & 13 & 15 & $\mathrm{E}$ & $\mathrm{D}$ \\
\hline 60 & Perk & 64 & 20 & 52 & 8 & 20 & $E$ & $\mathrm{D}$ \\
\hline G & \multicolumn{8}{|c|}{ Beverages } \\
\hline 61 & Bournvita & 75 & 45 & 28 & 9 & 17 & $\mathrm{~F}, \mathrm{E}$ & $\mathrm{D}$ \\
\hline 62 & Coca-Cola & 76 & 11 & 42 & 26 & 21 & $\mathrm{E}, \mathrm{S}, \mathrm{R}$ & $\mathrm{C}$ \\
\hline 63 & Complan & 73 & 45 & 25 & 14 & 16 & $F, E$ & $\mathrm{P}$ \\
\hline 64 & Frooti & 72 & 21 & 40 & 17 & 22 & $\mathrm{E}, \mathrm{R}$ & $\mathrm{P}$ \\
\hline 65 & Glucon-D & 81 & 59 & 19 & 10 & 12 & $\mathrm{~F}$ & $\mathrm{P}$ \\
\hline 66 & Horlicks & 80 & 45 & 29 & 6 & 20 & $\mathrm{~F}, \mathrm{E}$ & $\mathrm{P}$ \\
\hline 67 & Pepsi & 83 & 7 & 51 & 24 & 18 & $E$ & $\mathrm{C}$ \\
\hline 68 & Real & 66 & 35 & 39 & 15 & 11 & $\mathrm{E}, \mathrm{F}$ & $\mathrm{P}$ \\
\hline 69 & Tata Tea & 78 & 17 & 29 & 14 & 40 & $\mathrm{R}, \mathrm{E}$ & C \\
\hline 70 & Thums Up & 73 & 11 & 41 & 32 & 16 & $\mathrm{E}, \mathrm{S}$ & $\mathrm{P}$ \\
\hline
\end{tabular}


R Harish Association between Brand Architecture and Brand Concept

\begin{tabular}{|c|c|c|c|c|c|c|c|c|}
\hline \multirow[b]{2}{*}{$\begin{array}{l}\dot{z} \\
\dot{\omega}\end{array}$} & \multirow[b]{2}{*}{ 苞 } & \multirow{2}{*}{ 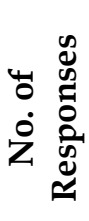 } & \multicolumn{4}{|c|}{ Brand Concept Score \% } & \multirow{2}{*}{ ত } & \multirow{2}{*}{ 己 } \\
\hline & & & $\mathbf{F}$ & E & $S$ & $\mathbf{R}$ & & \\
\hline $\mathbf{H}$ & \multicolumn{8}{|c|}{ Other Food Products } \\
\hline 71 & Amul & 75 & 19 & 19 & 11 & 52 & $\mathrm{R}$ & $\mathrm{C}$ \\
\hline 72 & Britannia & 71 & 18 & 20 & 15 & 46 & $\mathrm{R}$ & $\mathrm{C}$ \\
\hline 73 & Kissan & 54 & 43 & 31 & 7 & 19 & $\mathrm{~F}, \mathrm{E}$ & $\mathrm{P}$ \\
\hline 74 & Kurkure & 57 & 30 & 49 & 5 & 16 & $\mathrm{E}, \mathrm{F}$ & $\mathrm{P}$ \\
\hline 75 & $\begin{array}{l}\text { Kwality/ } \\
\text { Kwality Walls }\end{array}$ & 58 & 16 & 38 & 19 & 28 & $\mathrm{E}, \mathrm{R}, \mathrm{S}$ & $\mathrm{P}$ \\
\hline 76 & Maggi & 78 & 15 & 29 & 10 & 45 & $\mathrm{R}, \mathrm{E}$ & $\mathrm{D}$ \\
\hline 77 & Parle (Biscuits) & 66 & 26 & 15 & 9 & 50 & $\mathrm{R}, \mathrm{F}, \mathrm{S}, \mathrm{E}$ & $\mathrm{C}$ \\
\hline 78 & Sunfeast & 56 & 32 & 43 & 9 & 16 & $\mathrm{E}, \mathrm{F}$ & $\mathrm{P}$ \\
\hline 79 & Tata Salt & 81 & 31 & 12 & 7 & 49 & $\mathrm{R}, \mathrm{F}, \mathrm{S}, \mathrm{E}$ & C \\
\hline 80 & $\begin{array}{l}\text { Uncle } \\
\text { Chipps }\end{array}$ & 53 & 32 & 38 & 6 & 25 & $\mathrm{E}, \mathrm{F}$ & $\mathrm{P}$ \\
\hline $\mathbf{I}$ & \multicolumn{8}{|c|}{ Apparel, Footwear \& Accessories } \\
\hline 81 & HMT & 57 & 44 & 19 & 9 & 28 & $\mathrm{~F}, \mathrm{R}$ & C \\
\hline 82 & Titan & 83 & 12 & 14 & 39 & 35 & $S, R$ & $\mathrm{C}$ \\
\hline $\mathbf{J}$ & \multicolumn{8}{|c|}{ Consumer Durables } \\
\hline 83 & Asian Paints & 69 & 25 & 20 & 25 & 30 & $\mathrm{R}, \mathrm{F}, \mathrm{S}, \mathrm{E}$ & C \\
\hline 84 & LG & 70 & 31 & 20 & 33 & 16 & $\mathrm{~S}, \mathrm{~F}, \mathrm{E}$ & C \\
\hline 85 & Onida & 64 & 45 & 20 & 17 & 17 & $\mathrm{~F}$ & $\mathrm{C}$ \\
\hline 86 & Philips & 63 & 40 & 22 & 27 & 11 & $\mathrm{~F}, \mathrm{~S}, \mathrm{E}$ & C \\
\hline 87 & Samsung & 62 & 35 & 24 & 24 & 16 & $\mathrm{~F}, \mathrm{E}, \mathrm{S}$ & $\mathrm{C}$ \\
\hline 88 & Sony & 79 & 22 & 18 & 41 & 20 & $\mathrm{~S}, \mathrm{~F}$ & $\mathrm{C}$ \\
\hline 89 & Videocon & 65 & 55 & 14 & 12 & 18 & $\mathrm{~F}$ & $C$ \\
\hline 90 & Whirlpool & 62 & 39 & 29 & 23 & 10 & $\mathrm{~F}, \mathrm{E}, \mathrm{S}$ & C \\
\hline
\end{tabular}




\begin{tabular}{|c|c|c|c|c|c|c|c|c|}
\hline \multirow{2}{*}{$\begin{array}{l}\dot{z} \\
\dot{n}\end{array}$} & \multirow{2}{*}{ 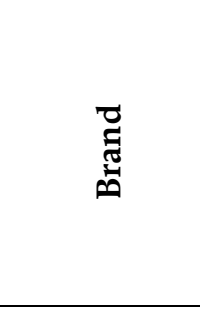 } & \multirow{2}{*}{ 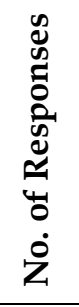 } & \multicolumn{4}{|c|}{$\begin{array}{c}\text { Brand Concept } \\
\text { Score } \% \\
\end{array}$} & \multirow{2}{*}{ 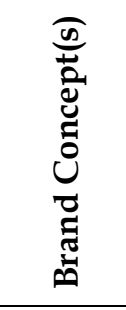 } & \multirow{2}{*}{ 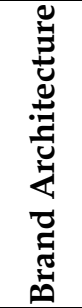 } \\
\hline & & & F & E & $S$ & $\mathbf{R}$ & & \\
\hline K & \multicolumn{8}{|c|}{ Automobiles } \\
\hline 91 & Bajaj Pulsar & 70 & 20 & 19 & 47 & 14 & S & $\mathrm{D}$ \\
\hline 92 & HH Passion & 64 & 39 & 9 & 25 & 27 & $\mathrm{~F}, \mathrm{R}, \mathrm{S}$ & D \\
\hline 93 & $\begin{array}{l}\mathrm{HH} \\
\text { Splendor }\end{array}$ & 68 & 35 & 9 & 21 & 35 & $\mathrm{R}, \mathrm{F}, \mathrm{S}$ & D \\
\hline 94 & $\begin{array}{l}\text { Honda } \\
\text { Activa }\end{array}$ & 61 & 43 & 16 & 28 & 13 & $\mathrm{~F}, \mathrm{~S}$ & D \\
\hline 95 & Maruti 800 & 61 & 46 & 11 & 10 & 33 & $F, R$ & D \\
\hline 96 & $\begin{array}{l}\text { Maruti } \\
\text { Esteem }\end{array}$ & 59 & 20 & 20 & 37 & 22 & $S, R, F, E$ & $\mathrm{D}$ \\
\hline 97 & Tata Indica & 56 & 46 & 7 & 16 & 30 & $\mathrm{~F}, \mathrm{R}$ & D \\
\hline 98 & Tata Sumo & 60 & 48 & 20 & 20 & 12 & $\mathrm{~F}, \mathrm{E}, \mathrm{S}$ & D \\
\hline 99 & TVS Scooty & 56 & 46 & 13 & 21 & 20 & $\mathrm{~F}$ & D \\
\hline 100 & TVS Victor & 45 & 69 & 7 & 11 & 13 & $\mathrm{~F}$ & $\mathrm{D}$ \\
\hline
\end{tabular}

Brand Concepts: $\mathrm{F}=$ Functional, $\mathrm{E}=$ Experiential, $\mathrm{S}=$ Symbolic and $\mathrm{R}=$ Relational

Brand Architectures: $\mathrm{P}=$ Product Dominant, $\mathrm{D}=$ Dual and $\mathrm{C}=$ Corporate Dominant

Table 2 contains a summarized cross-tabulation of the brand concepts and brand architecture types in terms of both numbers and percentages. 
R Harish Association between Brand Architecture and Brand Concept

Table 2: Brand Concept \& Brand Architecture Matrix

\begin{tabular}{|c|c|c|c|c|c|c|c|c|}
\hline \multirow{3}{*}{$\begin{array}{c}\begin{array}{c}\text { Brand } \\
\text { Concept }\end{array} \\
\mathrm{F}\end{array}$} & \multicolumn{6}{|c|}{ Brand Architecture } & \multirow{2}{*}{\multicolumn{2}{|c|}{ Total }} \\
\hline & \multicolumn{2}{|c|}{ Product (P) } & \multicolumn{2}{|c|}{ Dual (D) } & \multicolumn{2}{|c|}{ Corporate (C) } & & \\
\hline & 23 & $72 \%$ & 2 & $6 \%$ & 7 & $22 \%$ & 32 & $100 \%$ \\
\hline & $43 \%$ & & $10 \%$ & & $27 \%$ & & $32 \%$ & \\
\hline \multirow[t]{2}{*}{$F \& E$} & 18 & $86 \%$ & 3 & $14 \%$ & -- & $0 \%$ & 21 & $100 \%$ \\
\hline & $33 \%$ & & $16 \%$ & & $0 \%$ & & $21 \%$ & \\
\hline \multirow[t]{2}{*}{$E$} & -- & $0 \%$ & 4 & $80 \%$ & 1 & $20 \%$ & 5 & $100 \%$ \\
\hline & $0 \%$ & & $21 \%$ & & $4 \%$ & & $5 \%$ & \\
\hline \multirow[t]{2}{*}{$S$} & -- & $0 \%$ & 1 & $100 \%$ & -- & $0 \%$ & 1 & $100 \%$ \\
\hline & $0 \%$ & & $5 \%$ & & $0 \%$ & & $1 \%$ & \\
\hline \multirow[t]{2}{*}{$F \& S$} & -- & $0 \%$ & 1 & $50 \%$ & 1 & $50 \%$ & 2 & $100 \%$ \\
\hline & $0 \%$ & & $5 \%$ & & $4 \%$ & & $2 \%$ & \\
\hline \multirow[t]{2}{*}{$E \& S$} & 2 & $100 \%$ & -- & $0 \%$ & -- & $0 \%$ & 2 & $100 \%$ \\
\hline & $4 \%$ & & $0 \%$ & & $0 \%$ & & $2 \%$ & \\
\hline \multirow[t]{2}{*}{ F, E \& S } & 3 & $38 \%$ & 1 & $13 \%$ & 4 & $50 \%$ & 8 & $100 \%$ \\
\hline & $6 \%$ & & $5 \%$ & & $15 \%$ & & $8 \%$ & \\
\hline \multirow[t]{2}{*}{$\mathrm{F}, \mathrm{S} \& \mathrm{R}$} & -- & $0 \%$ & 2 & $100 \%$ & -- & $0 \%$ & 2 & $100 \%$ \\
\hline & $0 \%$ & & $10 \%$ & & $0 \%$ & & $2 \%$ & \\
\hline \multirow[t]{2}{*}{$\mathrm{R}$} & -- & $0 \%$ & -- & $0 \%$ & 2 & $100 \%$ & 2 & $100 \%$ \\
\hline & $0 \%$ & & $0 \%$ & & $8 \%$ & & $2 \%$ & \\
\hline \multirow[t]{2}{*}{ S, E \& R } & 1 & $20 \%$ & -- & $0 \%$ & 4 & $80 \%$ & 5 & $100 \%$ \\
\hline & $2 \%$ & & $0 \%$ & & $15 \%$ & & $5 \%$ & \\
\hline \multirow[t]{2}{*}{$S, E, R \& F$} & -- & $0 \%$ & 1 & $20 \%$ & 4 & $80 \%$ & 5 & $100 \%$ \\
\hline & $0 \%$ & & $5 \%$ & & $15 \%$ & & $5 \%$ & \\
\hline \multirow[t]{2}{*}{ S\&R } & -- & $0 \%$ & -- & $0 \%$ & 1 & $100 \%$ & 1 & $100 \%$ \\
\hline & $0 \%$ & & $0 \%$ & & $4 \%$ & & $1 \%$ & \\
\hline \multirow[t]{2}{*}{ F \& R } & 2 & $40 \%$ & 2 & $40 \%$ & 1 & $20 \%$ & 5 & $100 \%$ \\
\hline & $4 \%$ & & $10 \%$ & & $4 \%$ & & $5 \%$ & \\
\hline \multirow[t]{2}{*}{ E \& R } & 2 & $40 \%$ & 2 & $40 \%$ & 1 & $20 \%$ & 5 & $100 \%$ \\
\hline & $2 \%$ & & $10 \%$ & & $4 \%$ & & $5 \%$ & \\
\hline \multirow[t]{2}{*}{$\mathrm{F}, \mathrm{E} \& \mathrm{R}$} & 4 & $100 \%$ & -- & $0 \%$ & -- & $0 \%$ & 4 & $100 \%$ \\
\hline & $7 \%$ & & $0 \%$ & & $0 \%$ & & $4 \%$ & \\
\hline \multirow[t]{2}{*}{ Total } & 55 & $55 \%$ & 19 & $19 \%$ & 26 & $26 \%$ & 100 & $100 \%$ \\
\hline & $100 \%$ & & $100 \%$ & & $100 \%$ & & $100 \%$ & \\
\hline
\end{tabular}

Note:

Brand Concepts: $\mathrm{F}=$ Functional, $\mathrm{E}=$ Experiential, $\mathrm{S}=$ Symbolic and $\mathrm{R}=$ Relational

The observations emerging there from are presented in Table 3. 
Table 3: Observations Emerging From the Study

\begin{tabular}{|c|c|c|}
\hline No. & Observation & Whether in General Agreement with BASE \\
\hline 1 & $\begin{array}{l}\text { Most of the Product brands are } \\
\text { perceived by the respondents to } \\
\text { be reflecting either Functional - F } \\
(43 \%) \text { or Functional-Experiential, } \\
\text { i.e., F\&E }(33 \%) \text { concepts. }\end{array}$ & $\begin{array}{l}\text { No. BASE advocates Product brands to have } \\
\text { Experiential and Symbolic concepts. }\end{array}$ \\
\hline 2 & $\begin{array}{l}\text { Majority of Dual brands (63\%) } \\
\text { are associated with multiple } \\
\text { brand concepts (i.e., F\&E, F,S\&R, } \\
\text { E\&R, F\&R, etc.). Further, } 37 \% \\
\text { have one of the concepts as } \\
\text { Relational. }\end{array}$ & $\begin{array}{l}\text { Yes. In a Dual brand, the two brands bring } \\
\text { together two different concepts. As } \\
\text { expected, the Relational concept is a } \\
\text { common thread in many of the cases. The } \\
\text { Relational concept is contributed by the } \\
\text { parent brand (i.e., corporate brand), while } \\
\text { the functional, experiential or symbolic } \\
\text { concept is contributed by the sub-brand (i.e., } \\
\text { product brand). }\end{array}$ \\
\hline 3 & $\begin{array}{l}\text { Though only a few Corporate } \\
\text { brands are perceived as being } \\
\text { purely Relational, it is one of the } \\
\text { concepts that company brands } \\
\text { are identified with in } 50 \% \text { of the } \\
\text { cases (e.g., S,E\&R; S,E,R\&F; S\&R; } \\
\text { etc.) }\end{array}$ & $\begin{array}{l}\text { Yes. According to BASE, Corporate } \\
\text { branding is applicable to Functional and } \\
\text { Relational Concepts. }\end{array}$ \\
\hline 4 & $\begin{array}{l}27 \% \text { of Corporate brands are } \\
\text { perceived by respondents as } \\
\text { being Functional. A further } 38 \% \\
\text { of Corporate brands have } \\
\text { Functional as one of the multiple } \\
\text { concepts. }\end{array}$ & Yes. For the same reason as above. \\
\hline 5 & $\begin{array}{l}\text { Brands that are perceived to be } \\
\text { Functional (either exclusively or } \\
\text { together with other brand } \\
\text { concepts) by the respondents are } \\
\text { predominantly Product brands } \\
(63 \%) \text {, with Corporate brands } \\
(22 \%) \text { and Dual brands }(15 \%) \\
\text { being in the minority. }\end{array}$ & $\begin{array}{l}\text { No. BASE advocates that Functional concept } \\
\text { is primarily associated with Corporate } \\
\text { dominant branding, followed by Dual } \\
\text { branding. }\end{array}$ \\
\hline 6 & $\begin{array}{l}\text { Brands which are designated as } \\
\text { Experiential (either exclusively } \\
\text { or as one among two or more } \\
\text { concepts applicable to a brand) } \\
\text { are majorly Product brands } \\
(55 \%) \text {, followed by Corporate } \\
\text { brands }(25 \%) \text { and Dual brands } \\
(20 \%) \text {. }\end{array}$ & $\begin{array}{l}\text { Yes. BASE expects Experiential brands to be } \\
\text { Product brands (including Product-Target } \\
\text { brands), with a few also being Dual brands. }\end{array}$ \\
\hline
\end{tabular}




\begin{tabular}{|c|l|l|}
\hline No. & \multicolumn{1}{|c|}{ Observation } & Whether in General Agreement with BASE \\
\hline 7 & $\begin{array}{l}\text { Brands which are considered as } \\
\text { Symbolic (either exclusively or in }\end{array}$ & $\begin{array}{l}\text { No. BASE advocates that Symbolic brands } \\
\text { are mostly Product brands (in particular } \\
\text { association with other brand } \\
\text { Tanget brands), followed by Dual brands. } \\
\text { Concepts) are primarily } \\
\text { than Product brands (23\%) or } \\
\text { Dual brands (23\%) }\end{array}$ \\
\hline 8 & $\begin{array}{l}45 \% \text { of brands which have a } \\
\text { Relational concept (either }\end{array}$ & $\begin{array}{l}\text { Yes. According to BASE, Relational concept } \\
\text { is applicable to Corporate branding, } \\
\text { exclusively or along with other } \\
\text { concepts) are Corporate brands. } \\
\text { The rest are Product brands } \\
(31 \%) \text { and Dual brands (24\%). }\end{array}$ \\
\hline
\end{tabular}

\section{Findings}

Considering that we have a Yes to No ratio of 5:3 in the analysis presented in Table 1, we may state that there is a significant degree of alignment between the BASE model and the observations from the current study, though one cannot say that there is a very good match.

Conceptually, the BASE framework is quite logical and wellthought out. However, in actual practice, the brand architectures of companies are also influenced by a host of other factors, apart from the brand concepts themselves, thus deviating from what is proposed by BASE. These factors would include corporate structure and policy, brand baggage inherited from the past, mergers and acquisitions, industry practices, and brand architectures followed by competitors, among others. The challenge would be to integrate all the factors together and come up with a generally applicable framework for designing the brand architecture of a company.

Further, some of the proposals made by BASE depart significantly from what we observe in actual practice. For example, many product brands are based predominantly on the functional concept, while BASE associates product brands with experiential and symbolic concepts. Further, corporate brands with a connotation of prestige attached to them could reflect the symbolic concept, whereas BASE recommends functional and relational concepts to 
be promoted through corporate branding. Thus, further research could suggest some realignment of the BASE model itself.

The results could also vary with the context - the companies and brands that are included, the country or culture where the study is carried out, and the segment(s) of society considered therein.

Further, the findings are based on broad observation of the data and information gathered; and is not statistically validated. The objective and nature of the study necessitated a methodology which was not amenable for statistical validation. As such, the findings are of an exploratory nature and not conclusive.

\section{References:}

Aaker, D. A. \& Joachimsthaler, E. (2000), The Brand Relationship Spectrum: The Key to the Brand Architecture Challenge, California Management Review,. 42(4). Adapted from Brand Leadership by Aaker and Joachimsthaler (2000), The Free Press.

Kapferer, J. N. (1997), Strategic Brand Management: Creating and Sustaining Brand Equity Long Term, London, U.K., Kogan Page

Nielsen (2008), Most Trusted Brands 2008, The Economic Times, Brand Equity Supplement, June 11, 2008

Nielsen (2013), India's Most Trusted Brands 2013, The Economic Times, Brand Equity Supplement, December 18, 2013

Park, C. W., Jaworski, B. J., and MacInnis, D. J. (1986), Strategic Brand Concept - Image Management, Journal of Marketing, 50 (October), 135145.

Strebinger, A. (2004), Strategic Brand Concept and Brand Architecture Strategy - A Proposed Model, Advances in Consumer Research,.31, pp. 656-661. 